\title{
Evaluation of GFP reporter utility for analysis of transcriptional slippage during gene expression
}

\author{
Ewa Wons, Dawid Koscielniak, Monika Szadkowska and Marian Sektas* (i)
}

\begin{abstract}
Background: Epimutations arising from transcriptional slippage seem to have more important role in regulating gene expression than earlier though. Since the level and the fidelity of transcription primarily determine the overall efficiency of gene expression, all factors contributing to their decrease should be identified and optimized.

Results: To examine the influence of A/T homopolymeric sequences on introduction of erroneous nucleotides by slippage mechanism green fluorescence protein (GFP) reporter was chosen. The in- or out-of-frame gfp gene was fused to upstream fragment with variable number of adenine or thymine stretches resulting in several hybrid GFP proteins with diverse amino acids at N-terminus. Here, by using $T 7$ phage expression system we showed that the intensity of GFP fluorescence mainly depends on the number of the retained natural amino acids. While the lack of serine $\left(\mathrm{S}_{2}\right)$ residue results in negligible effects, the lack of serine and lysine $\left(\mathrm{S}_{2} \mathrm{~K}_{3}\right)$ contributed to a significant reduction in fluorescence by 2.7-fold for polyA-based in-frame controls and twofold for polyTs. What is more, N-terminal tails amino acid composition was rather of secondary importance, since the whole-cell fluorescence differed in a range of 9-18\% between corresponding polyA- and polyT-based constructs.

Conclusions: Here we present experimental evidence for utility of GFP reporter for accurate estimation of A/T homopolymeric sequence contribution in transcriptional slippage induction. We showed that the intensity of GFP hybrid fluorescence mainly depends on the number of retained natural amino acids, thus fluorescence raw data need to be referred to appropriate positive control. Moreover, only in case of GFP hybrids with relatively short N-terminal tags the fluorescence level solely reflects production yield, what further indicates the impact of an individual slippage sequence. Our results demonstrate that in contrast to the $E$. coli enzyme, T7 RNA polymerase exhibits extremely high propensity to slippage even on runs as short as 3 adenine or 4 thymine residues.
\end{abstract}

Keywords: Green fluorescent protein reporter, Transcriptional slippage, A/T homopolymers, T7 RNA polymerase, E. coli RNA polymerase

\section{Background}

Green fluorescent protein (GFP) from the Aequorea victoria jellyfish [1] is nowadays the most widely used and developed reporter applicable in biochemistry and cell biology [2]. GFP and its mutant derivatives possess internal fluorophore that re-emits light which covers visible spectrum of colors [3]. Hence, GFP technology is very

*Correspondence: marian.sektas@biol.ug.edu.pl Department of Microbiology, University of Gdansk, Wita Stwosza 59, 80-308 Gdansk, Poland attractive and easily adaptable to biotechnology and many fields of basic science. GFP is used as a protein fusion reporter in various applications in diverse kind of cells for imaging and detection of very specific processes, such as fusion gene expression, tagged protein in situ location, host-parasite interactions and others [2]. The hybrid protein maintains its normal function along with fluorescent property acquired from GFP expressing gene. The incorporation of GFP can be done at either the N- or C-terminus of a protein or peptide domain.

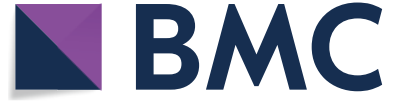

(c) The Author(s) 2018. This article is distributed under the terms of the Creative Commons Attribution 4.0 International License (http://creativecommons.org/licenses/by/4.0/), which permits unrestricted use, distribution, and reproduction in any medium, provided you give appropriate credit to the original author(s) and the source, provide a link to the Creative Commons license, and indicate if changes were made. The Creative Commons Public Domain Dedication waiver (http://creativecommons.org/ publicdomain/zero/1.0/) applies to the data made available in this article, unless otherwise stated. 
Epigenetic effects of ribosomal and transcriptional frameshifting play important role in regulating gene expression processes as it has clearly emerged from the accumulated and still growing knowledge in this field [4]. Our research concerns comparative analysis of the transcriptional slippage propensity of the two most widely used RNA polymerases (RNAPs): E. coli and T7 bacteriophage, representing two different families of enzymes [5]. Long mononucleotide A/T stretches destabilize and realign RNA:DNA hybrid, contributing to RNAP "slippage" throughout the DNA template. Productive transcriptional slippage at such sites involves unwindingrewinding of the RNA:DNA hybrid which is not sensed by RNAP active site and hereby does not lead to enzyme backtracking and mRNA correction. Forward and backward mRNA slippage generates insertion/deletion errors in nascent transcripts, resulting in shift of reading frame [6]. It is known that the error rate of transcripts generated by $E$. coli RNAP in vivo is significantly high, roughly between the values of $10^{-5}$ and $10^{-3}$ per residue [7], and even higher for T7 RNAP [6]. Insertion/deletion (indels) type of transcriptional errors may be considered as ambiguous. From one side they are detrimental to efficiency of gene expression, but on the other hand can also be beneficial for cell physiology. Transcriptional slippage has significant potential to restore the wild-type phenotype of indel mutant genes [6, 8-13]. Here, we evaluated GFP protein reporter for potential use in a study of the transcriptional slippage phenomenon which occurs during expression of out of frame fusion genes with upstream fragments containing $\mathrm{A} / \mathrm{T}$ homopolymeric sequences. The results demonstrate utility of GFP fusion gene to study transcriptional slippage effect in homopolymer sequence-dependent manner.

\section{Methods}

\section{Bacterial strains and culture conditions}

All cloning was performed using Escherichia coli (E. coli) DH10B strain $\left(\mathrm{F}^{-} \lambda^{-}\right.$mcrA $\Delta$ (mrr-hsdRMS-mcrBC) Ф80lacZ $\Delta \mathrm{M} 15 \Delta$ lacX74 recA1 endA1 araD139 $\Delta($ ara leu) 7697 gal $\mathrm{U}$ galK rpsL nupG) grown at $37{ }^{\circ} \mathrm{C}$ in Luria broth (LB) [14] supplemented with $50 \mu \mathrm{g} / \mathrm{ml}$ kanamycin or $100 \mu \mathrm{g} / \mathrm{ml}$ ampicillin for maintenance of pET24aor pBAD24-based plasmids, respectively [15, 16]. For fluorescence experiments E. coli ER2566 T7 phage RNAP IPTG inducible strain $\left(\mathrm{F}^{-} \lambda^{-}\right.$fhuA2 [lon] omp T lacZ::T7 gene 1 gal sulA11 $\Delta$ (mcrC-mrr)114::IS10 R(mcr73::miniTn10-Tet $\left.{ }^{\mathrm{S}}\right) 2 \mathrm{R}\left(z g b-210:: \operatorname{Tn} 10-\mathrm{Tet}^{\mathrm{S}}\right)$ end $\mathrm{A} 1$ [dcm] was used (New England Biolabs, Ipswich, USA).

\section{Genetic techniques}

Standard protocols [14] and kits were used for purification of plasmid DNA (A\&A Biotechnology, Gdynia,
Poland), digestion of DNA with restriction endonucleases, ligation of DNA with T4 DNA ligase and PCR techniques with PfuPlus DNA polymerase (all from $E R_{x}$, Gdansk, Poland).

\section{Vector construction}

pET24a derivative reporter vectors (Additional file 1: Table S1) were constructed using PCR to amplify a 900bp fragment of pGreenTIR plasmid [17], a source of enhanced fluorescence $g f p$ variant (F64L/S65T) [18], and different set of primers (Additional file 1: Table S2) provided three reading frames $(-1,0$ and +1$)$. The resulting PCR fragment containing the promoterless $g f p$ gene was digested with BamHI and EcoRI and cloned into the same sites of pET24a. Next, sets of two annealed oligonucleotides (Additional file 1: Table S2) carrying appropriate polyA/T sequences were inserted into NheI-BamHI sites and ligated. All resulting fusion genes were confirmed by sequencing (Genomed, Warszawa, Poland), and then, as XbaI-HindIII fragments were subcloned into pBAD24 plasmid.

\section{Site-directed mutagenesis}

Site-specific mutagenesis using PCR was carried by high fidelity PfuPlus DNA polymerase (Eur ${ }_{x}$ ) according to the manufacturer's instructions (50 ng of plasmid template was added to a $50-\mu \mathrm{l}$ PCR reaction). Appropriate plasmid templates and nucleotide deletion/insertion in reverse primers were PCR-amplified and parental plasmid was eliminated by digestion with $D p n I$ enzyme $(10 \mathrm{u}$, Thermo Scientific, Waltham, USA) for 1.5 -h at $37{ }^{\circ} \mathrm{C}$. Products were resolved in agarose gels, appropriate bands were cut out and aliquots containing purified DNA were transformed into DH10B competent cells. All plasmid modifications were confirmed by Sanger DNA sequencing using the BigDye Terminator v3.1 (Applied Biosystems, Waltham, USA) (Genomed). Additional file 1: Tables S1 and $\mathrm{S} 2$ include a list of plasmids and primers used.

\section{Whole cell fluorescence}

ER2566 cells were grown in LB medium, containing kanamycin or ampicillin, at $37^{\circ} \mathrm{C}$, until the culture reached an $\mathrm{OD}_{600}$ of $0.2-0.3$. Then, to induce expression of tested fusion genes isopropyl $\beta$-d-1-thiogalactopyranoside (IPTG) or L-arabinose were added to $1 \mathrm{mM}$ or $0.1 \%$, respectively, and cells were further incubated for additional $1 \mathrm{~h}$. Cells were gently harvested (400 $\mu$ l sample), resuspended in $200 \mu \mathrm{l} \mathrm{F}$ buffer (M9 salts; $0.1 \mathrm{mM} \mathrm{CaCl}_{2}$; $1 \mathrm{mM} \mathrm{MgSO}_{4}$ ) and then quantified using a Varioskan ${ }^{\circledR}$ Flash Spectral Scanning Multimode Reader (Thermo Scientific) at excitation and emission wavelengths of 485 and $510 \mathrm{~nm}$, respectively. The raw fluorescence intensity of each culture was normalized to cell density $\left(\mathrm{OD}_{600}\right)$ and 
the background fluorescence from $g f p$-less cells was subtracted from each reading.

\section{Western blotting for GFP protein}

Culture extracts, after normalization to $\mathrm{OD}_{600}$, were analyzed by $10 \%$ SDS-PAGE, transferred into nitrocellulose membrane and GFP protein detection was performed using mouse monoclonal anti-GFP (B-2) antibodies (Santa Cruz Biotechnology, Dallas, USA) diluted 1:4000 in TBS-T buffer $(50 \mathrm{mM}$ Tris- $\mathrm{HCl}, 150 \mathrm{mM} \mathrm{NaCl}, 0.05 \%$ Tween $20, \mathrm{pH} 7.6$ ) with $5 \%$ skimmed milk for $1.5 \mathrm{~h}$ at room temperature. After three washes with TBS-T, the membrane was incubated for $1 \mathrm{~h}$ with chicken antimouse IgG-HRP (horseradish peroxidase, 1:5000, Santa Cruz Biotechnology). The membrane was washed three times and the specific protein was visualized by adding chemiluminescent substrate solution (Pierce ECL Plus Western Blotting Substrate, Thermo Scientific) and exposed to X-ray film. For M2.MboII detection membrane was probed with rabbit anti-M2.MboII antibodies [19] diluted 1:1250 in TBS-T buffer, followed by incubation with a goat anti-rabbit secondary antibody conjugated with alkaline phosphatase $(1: 30,000$, SigmaAldrich, Saint Louis, USA). A specific protein was visualized by adding BCIP/NBT substrate solution (Thermo Scientific).

\section{RNA extraction and CDNA synthesis}

The cells were proceed as described in Whole cell fluorescence except after $1 \mathrm{~h}$ incubation with appropriate inducer cellular RNA was extracted with Total RNA Mini Plus Concentrator Kit (A\&A Biotechnology) according to the manufacturer's instructions. For the mRNA stability experiment culture samples were taken starting $30 \mathrm{~s}$ prior to addition of rifampicin $(250 \mu \mathrm{g} / \mathrm{ml}$, BioShop, Burlington, Canada). Culture sample volumes were corrected for OD to maintain similar cell numbers per sample. Samples were immediately mixed with $0.5 \mathrm{ml}$ of stayRNA protection buffer (A\&A Biotechnology). cDNA were obtained after RNase-free DNase I (Thermo Scientific) treatment by using RevertAid First Strand cDNA Synthesis Kit (Thermo Scietific).

\section{Northern blot detection}

Profiles of the $g f p$ fusion genes specific transcripts were analyzed by northern blotting. Equal amounts $(5 \mu \mathrm{g})$ of total RNA were loaded on formaldehyde denaturing 1.3\% agarose gel and then transferred onto Zeta-Probe ${ }^{\circledR}$ blotting membrane (BioRad, Hercules, USA) by capillary forces. PCR-produced 774 bp dsDNA fragment specific to the whole $g f p$ gene sequence (obtained with primers bamGFP6 and Gfpdown, Additional file 1: Table S2, and pGreenTIR as a template) after biotin labelling
(Biotin-High Prime, Roche Diagnostics, Basel, Switzerland) was used as a probe. Chemiluminescent detection was carried using streptavidin-HRP Pierce ECL substrate (Thermo Scientific) and exposure to X-ray film.

\section{Quantitative RT-PCR}

The specific primers, designed to ensure similar $T_{\mathrm{m}}$ and PCR product size, are given in Additional file 1: Table S2. $16 \mathrm{~S} r \mathrm{rn}$ was chosen as internal stable reference housekeeping gene, while in case of $g f p$ fusion variants $5^{\prime}$-end of transcripts was analyzed. Real-time PCR with LightCycler 2.0 (Roche Diagnostics) was performed in triplicate in three independent experiments using SG qPCR mix with SYBR Green $\left(\operatorname{Eur}_{x}\right)$. The PCR employed the following cycling parameters: $95{ }^{\circ} \mathrm{C}$ for $5 \mathrm{~min}$, followed by 35 cycles of $94{ }^{\circ} \mathrm{C}$ for $20 \mathrm{~s}, 60^{\circ} \mathrm{C}$ for $20 \mathrm{~s}, 72{ }^{\circ} \mathrm{C}$ for $10 \mathrm{~s}$ each; and finally the melting curve $\left(60-97^{\circ} \mathrm{C}\right)$ program for quality control, and cooling to $40{ }^{\circ} \mathrm{C}$. The levels of remaining mRNA for each variant was normalized to the level of the reference housekeeping gene $16 \mathrm{~S} \mathrm{rrn}$, and then determined by fitting the percentage of mRNA remaining vs. time to an exponential decay function. The relative fold-change mRNAs ratios were obtained by normalizing each time point data in reference to the earliest measurements. In all studies the half-lives of transcripts were determined by fitting the percentage of mRNA remaining vs. time to an exponential decay function. The relative fold-change mRNAs ratios were obtained by normalizing each time point data in reference to the earliest measurements [20].

\section{Analysis of the $\mathrm{N}$-terminal amino acid sequence of the $A_{5}$ GFP- 1 hybrid}

The $\mathrm{N}$-terminal protein sequence analysis was performed at BioCentrum Ltd. (Krakow, Poland). Sequentially detached phenylthiohydantoin derivatives of amino acids were identified using the Procise 491 (Applied Biosystems) automatic sequence analysis system, according to the standard protocol of the manufacturer.

\section{Results and discussion \\ Contribution of a short and long $\mathrm{N}$-terminal tags to the GFP fluorescence ability}

To determine how length and kind of nucleotides in the homopolymeric sequence affect the slippage events several fusions containing polyA and polyT sequences with downstream $g f p$ gene [17] were constructed. Expression of fusion gene was under control of the T7-phage promoter [16]. First, fusions with short or a long (proximal half of mboIIM2 gene [6]) fragments containing $\mathrm{A}_{8} / \mathrm{T}_{8}$ slippery sequences located upstream of the reporter $g f p$ in three frames $(-1,0$ and +1$)$ were tested (Fig. 1a, b). Both type of gene fusion genes were properly expressed, 


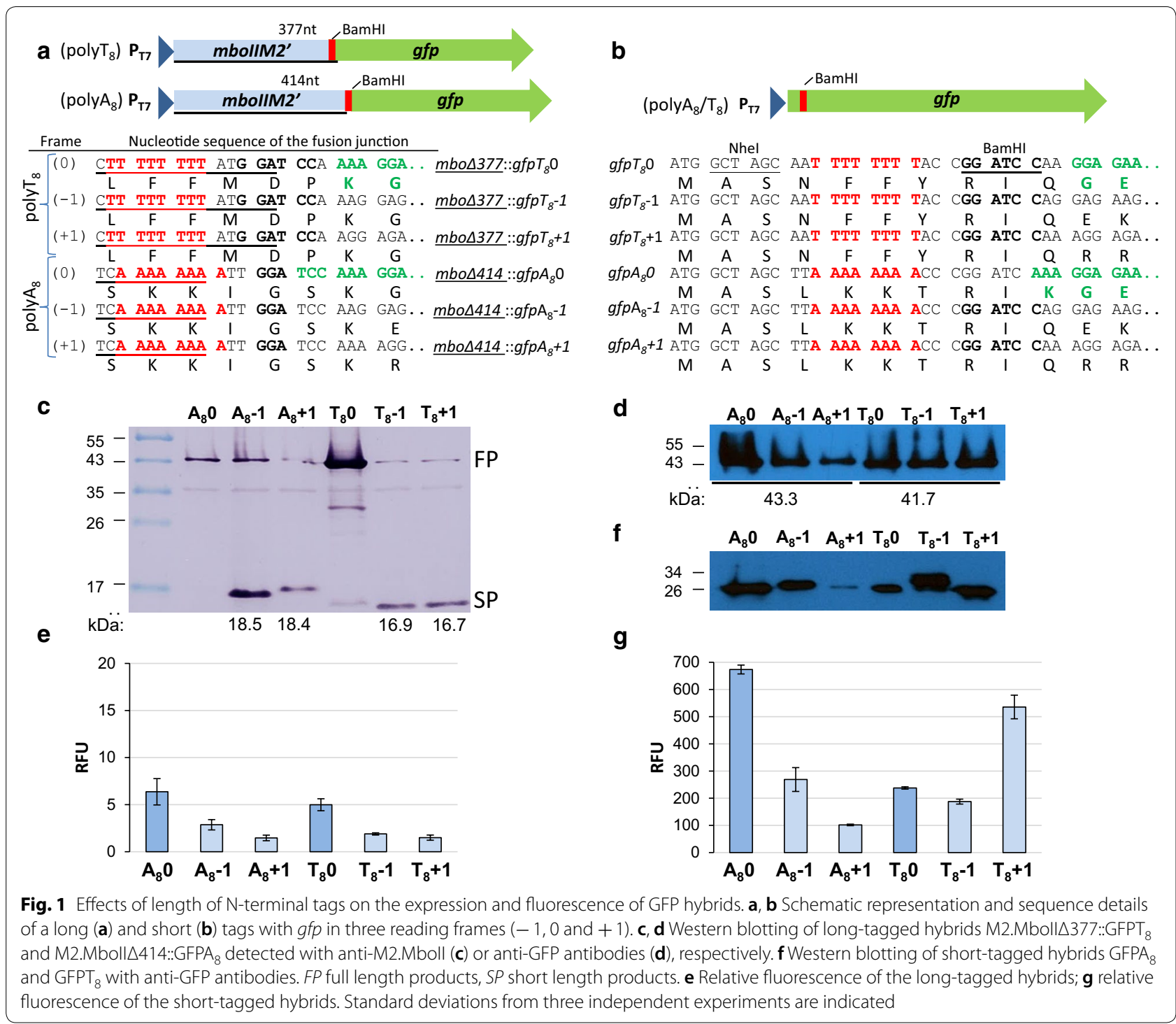

however only in case of short N-terminal tags the fluorescence ability of the hybrid GFP was not disturbed (Fig. 1g), thus short fusion type was chosen to further studies.

\section{Identification of GFP reporter slippage product}

Our analysis was began with high slippage-prone sequence TTAAAAACACC [6]. pETmin $\mathrm{A}_{5}$ gfp-1 vector was constructed to contain PCR-created $g f p$ gene in -1 reading frame and an 18-bp duplex DNA carrying the homopolymer sequence inserted between NheI-BamHI sites of pET24a vector (Fig. 2a), so as to apply the principle of avoiding the NGG codons [21]. Slippage efficiency of out-of-frame hybrid was indicated by the whole-cell fluorescence level referred to in-frame control. This in-frame $g f p A_{6} O$ fusion was designed to have the same nucleotide/amino acids pattern as the most likely product of erroneous single nucleotide insertion in $g f p A_{5}-1$. Apart from 8 amino acid $\mathrm{N}$-terminal tag this $\mathrm{GFPA}_{5}-1$ variant preserved all native GFP amino acids $\left(\mathrm{S}_{2} \mathrm{~K}_{3} \mathrm{G}_{4} \mathrm{E}_{5} \mathrm{E}_{6} \mathrm{~L}_{7} \ldots\right)$ and was capable of rescuing fluorescence up to $27 \%$ of the positive control level (Fig. 2b). We established that under our conditions observed fluorescence intensity was proportional to GFP hybrid yield (Additional file 1: Figure S1). To confirm whether $\mathrm{GFPA}_{5}-1$ hybrid protein was produced through site-specific slippage, the purified protein was subjected to $\mathrm{N}$-terminal amino acid microsequencing by automated Edman degradation (BioCentrum, Poland). The sequence of the first 10 amino acid residues $\left(\mathrm{A}_{2} \mathrm{~S}_{3} \mathrm{~L}_{4} \mathrm{~K}_{5} \mathrm{~N}_{6} \mathrm{~T}_{7} \mathrm{G}_{8} \mathbf{S}_{9} \mathbf{K}_{10} \mathbf{G}_{11}\right)$ was found to be 


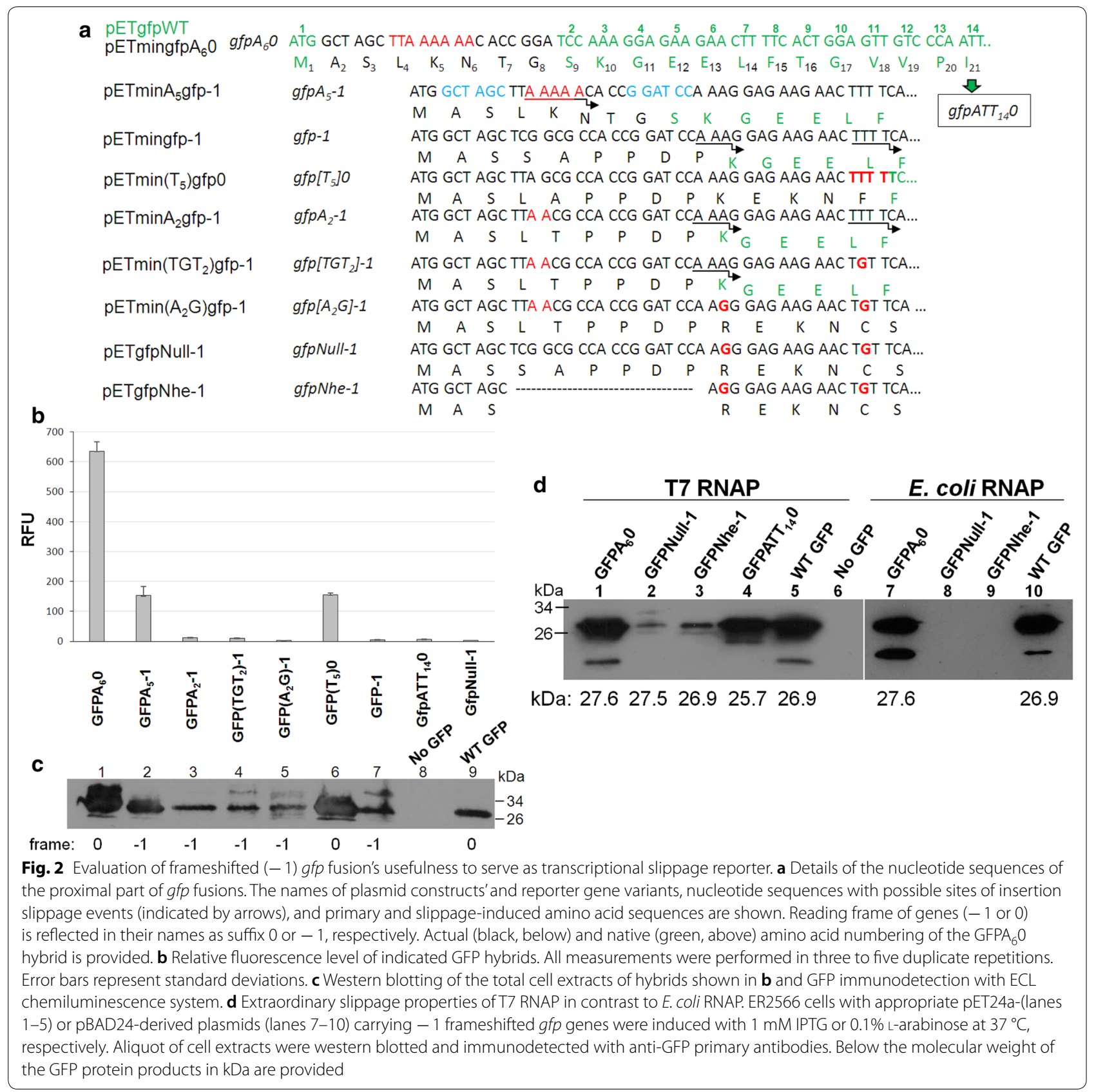

consistent with predicted after single adenine insertion into $\operatorname{poly}\left(\mathrm{A}_{5}\right)$ site $(5 \mathrm{~A} \rightarrow 6 \mathrm{~A})$.

\section{Testing the proximal part of $g$ fp gene for the possibility of an "surplus" slippage by T7 RNAP}

To make sure that the detectable GFP fluorescence is owed only to the tested slippage sequence, the proximal part of $g f p$ gene was examined for generating unexpected slippage or translational initiation from an alternative start codons. We checked possibility of production of truncated but functional GFP protein, by constructing -1 frameshifted $g f p-1$ fusion without any long slippery sequence (pETmingfp-1) and found it to manifest low fluorescence level, little above background (Fig. 2a, b). We reasoned that slight GFP protein production/activity was possible through slippage occurred at alternative sites located in the proximal part of $g f p$ : AAA (27-29 nt) or TTTT (40-43 nt) (Fig. 2b, c). Such amazing ability of T7 RNAP to slip on the template containing at least three nucleotide repeats was already reported in in vitro 
experiments [22]. We confirmed possibility of bypassing single nucleotide deletion through slippage at $\mathrm{T}_{4}$ site by construction a $\mathrm{pETmin}\left(\mathrm{T}_{5}\right)$ gfp0 vector with inframe $g f p$ fusion gene "hopping" into the appropriate 0 frame by addition of a single $\mathrm{T}$ to the normally present four (15th amino acid). The resulting mutant variant GFP $\left[\mathrm{T}_{5}\right] 0$, despite lacking 7 native $\mathrm{N}$-end amino acids $\left(\mathrm{M}_{1} \mathrm{~A}_{2} \mathrm{~S}_{3} \mathrm{~L}_{4} \mathrm{~A}_{5} \mathrm{P}_{6} \mathrm{P}_{7} \mathrm{D}_{8} \mathrm{P}_{9} \mathrm{~K}_{10} \mathrm{E}_{11} \mathrm{~K}_{12} \mathrm{~N}_{13} \mathrm{~F}_{14} \mathbf{F}_{15(8)} \mathbf{T}_{16(9)} \mathbf{G}_{17(\mathbf{1 0})}\right)$ exhibited $22 \%$ fluorescence compared to $\mathrm{GFPA}_{6} \mathrm{O}$ positive control. Moreover, the importance of $\mathrm{T}_{4}$ run in restoration of the proper frame was confirmed by interruption of its continuity ( $\left.g f p\left[T G T_{2}\right]-1\right)$. Such a construct (pETmin $\left(\mathrm{TGT}_{2}\right)$ gfp-1) showed decreased fluorescence by about $27 \%$ compared to $\mathrm{pETmin} \mathrm{A}_{2}$ gfp- 1 with full $\mathrm{T}_{4}$ run, yet its level was 4 times higher than background fluorescence (Fig. 2b, c). This suggested likely contribution of AAA sequence in slippage induction, what was further verified with a pETmin $\left(\mathrm{A}_{2} \mathrm{G}\right) \mathrm{gfp}$-1construct in which triple A sequence was modified $\left(g f p\left[A_{2} G\right]-1\right)$. Indeed, we observed subsequent decrease in GFP activity/production, but it reached little over the background.

To exclude the possibility, that fluorescent active GFP protein might be produced from a rare alternative start codon ATT [23], pETgfpATT ${ }_{14} 0$ was constructed. In this variant $g f p$ gene began from the 14th codon, which in the wild type is ATT, here substituted with ATG. Although we observed production of hybrid protein (Fig. 2d), yet no fluorescence was detected (Fig. 2b). This result is in agreement with data obtained by Raghunathan [24]. Interestingly, we detected remnant production of GFP even in case of -1 frameshifted $g f p N u l l-1$ and $g f p N h e-1$ genes which lacked any triple $\mathrm{A} / \mathrm{T}$ nucleotide in the $5^{\prime}$-terminal part of fusion gene (Fig. 2d). All of this indicates extremely high inclination of T7 RNAP to erroneous transcription, quite opposite to E. coli host RNAP (Fig. 2d).

\section{Relation between the intensity of hybrid GFP fluorescence and the number of retained natural amino acids}

Next, in order to examine fluorescence ability of GFP inframe variants, a set of 0 frame fusion genes expressing GFP with various polyA/T tags was constructed (Fig. 3). Several studies determined tolerance of GFP protein to amino acid deletions at its N-terminus [25-29] and few to $\mathrm{N}$-terminus insertions [30,31]. However, to date, there is no universal rule indicating the impact of an additional amino acid at the $\mathrm{N}$-terminus. As shown in Fig. 3, the relative levels of GFP hybrid fluorescence depended

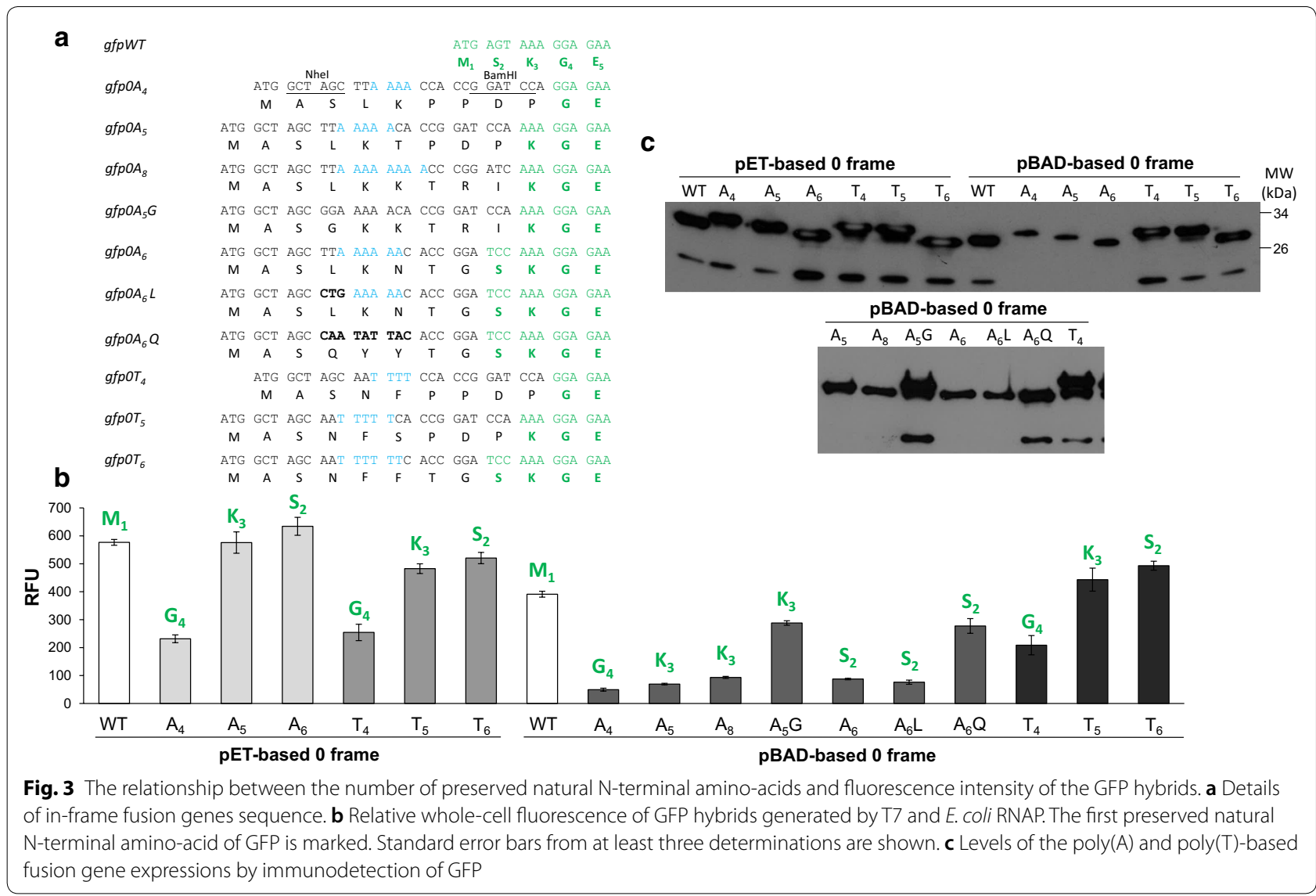


mainly on the number of retained natural amino acids, at least in the case of transcription driven by $\mathrm{T} 7$ phage RNAP. The lack of serine $\left(\mathrm{S}_{2}\right)$ residue results in negligible negative effects $(10 \%)$, while the lack of serine and lysine $\left(\mathrm{S}_{2} \mathrm{~K}_{3}\right)$ contributed to a significant reduction in fluorescence by 2.7-fold for polyA-based in-frame controls and twofold for polyTs. In the latter case, fluorescence level profile obtained with E. coli RNAP was quite similar, contrary to the polyA-based constructs, where for E. coli RNAP we observed a significant fivefold reduction in the fluorescence intensity (Fig. 3b). This is in agreement with low level of GFP production visualized by immunodetection (pBADgfp $\mathrm{A}_{4} 0-\mathrm{A}_{6} 0$, Fig. 3c). Since this effect occurred only for $E$. coli RNAP driven expression [32, 33 ], we ascribe it to the enzyme's exceptional sensitivity to the mRNA regulatory region located downstream of the initiation codon (both constructs employ the same T7 RBS region), which impacts the translation speed resulting from interplay of multiple factors like codon bias, mRNA secondary structure, and co-translational protein folding coordination [31, 34-38]. Many studies have already shown that codon usage, codon pairs and their order in $5^{\prime}$-terminus are non-random and greatly influence protein production [21, 30, 39-45]. Therefore, we asked whether the rare leucine codon $\mathrm{TTA}_{4}$ could entail reduction of expression. It was replaced with five times more frequently used in $E$. coli $\mathrm{CTG}_{4}$ codon, but without any effect in the expression level. Whereas when it was exchanged for glycine codon $\mathrm{GGA}_{4}\left(g f p A_{5} \mathrm{GO}\right)$ threefold higher fluorescence was detected. Next, A-rich codons for $\mathrm{L}_{4} \mathrm{~K}_{5} \mathrm{~N}_{6}\left(\mathrm{TTA}_{4} \mathrm{AAA}_{5} \mathrm{AAC}_{6}\right.$ ) were substituted with other A/T-rich codon array of $\mathrm{Q}_{4} \mathrm{Y}_{5} \mathrm{Y}_{6}\left(\mathrm{CAA}_{4} \mathrm{TAT}_{5}\right.$ $\left.\mathrm{TAC}_{6}\right)$ amino acids $\left(g f p A_{6} \mathrm{QO}\right)$. Those substituting amino acids are similar in their properties to $\mathrm{N}_{4} \mathrm{~F}_{5} \mathrm{~F}_{6}\left(\mathrm{AAT}_{4} \mathrm{TTT}\right.$ ${ }_{5} \mathrm{TTC}_{6}$ ) present in $\mathrm{GFPT}_{6} \mathrm{O}$ hybrid, which exhibits high level fluorescence intensity. Indeed, in $\mathrm{Q}_{4} \mathrm{Y}_{5} \mathrm{Y}_{6}$ construct threefold higher fluorescence level was detected (Fig. 3b). Level of $g f p A_{6} O$-construct mRNA was compared to $g f p T_{6} O$ and we found them equal both in northern blot analysis (Fig. 4a) as well as in quantitative RT-PCR (data not shown). We suggest that the codon context rule applies here in this specific pair of $\mathrm{L}_{4} \mathrm{~K}_{5}$ codons [32, 33]. However, in case of $E$. coli RNAP generated $g f p A_{6} O$ samples prominent product of the full-length mRNA degradation was reproducibly observed (Fig. 4a, lanes 1 and 4 vs. lanes 2 and 5). To test whether differences in protein production level arise from differential mRNA stability, we measured the rate of decay patterns of each mRNA species following culture treatment with the transcription initiation inhibitor rifampicin (Fig. 4b). Indeed, polyA mRNA exhibited significantly shorter half-life than polyT ( $1 \pm 0.001 \mathrm{~min}$ vs. $4.4 \pm 0.13 \mathrm{~min}$, respectively). Zucker MFold prediction program (mfold.rit.albany.edu)
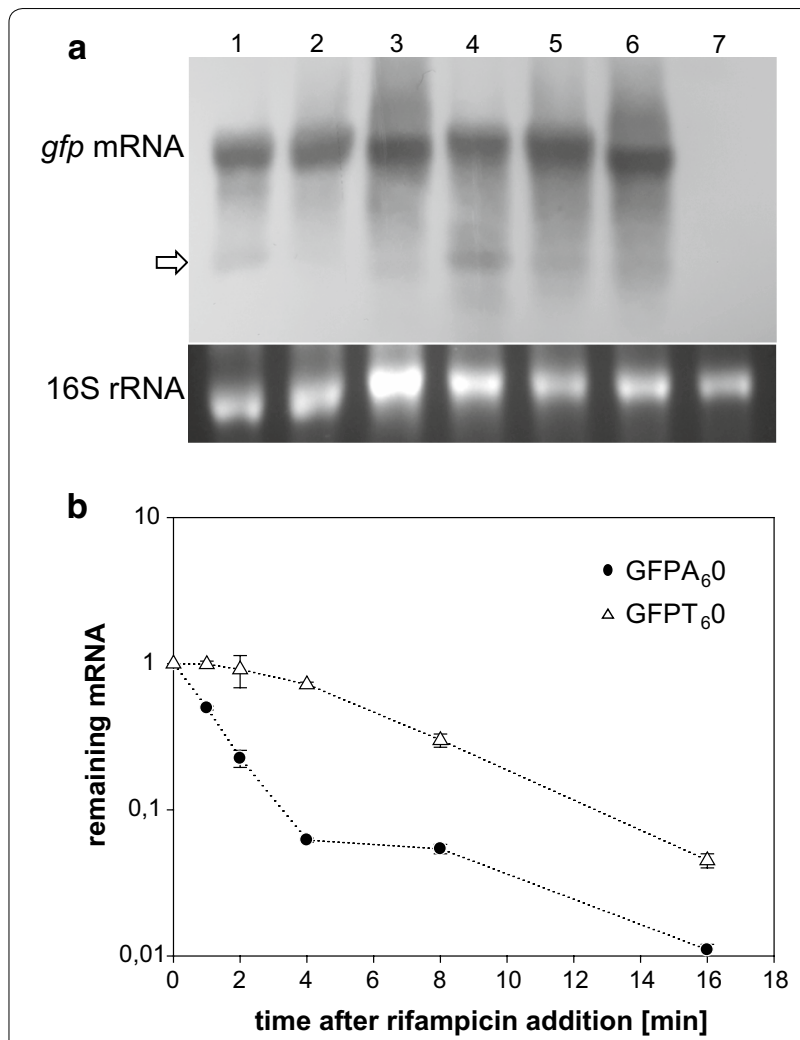

Fig. 4 Analysis of polyA- and polyT-based gfp mRNA levels and stability. a Top panel: total mRNA was extracted from E. coli ER2566 bearing pBADmingfp $\mathrm{A}_{6} \mathrm{O}$, pBADmingfp $\mathrm{T}_{6} \mathrm{O}$ and $\mathrm{pETmingfp} \mathrm{A}_{6} \mathrm{O}$ plasmids after 10 min (lanes 1-3) and 30 min expression (lanes 4-6), respectively, generated by E. coli (lanes 1, 2, 4 and 5) or T7 phage RNAP (lanes 3 and 6). The membrane was probed with biotin labelled gfp DNA. Lane 7, no-gfp control bacteria. Arrow-prominent degradation product. Bottom panel: ethidium bromide-stained $16 \mathrm{~S}$ rRNA are shown as loading control. b gfp transcripts stability. Rifampicin was added to an exponential culture of E. coli ER2655 growing in LB medium after 10 min of $0.1 \%$ L-arabinose induction. The mRNA levels were determined by RT-qPCR, using stable 165 rRNA as the internal standard. The circles represent $g f p A_{6} O$ and triangles represent gfp $_{6} 0$ transcripts. All mRNA levels were normalized to 1 at time $=0$ (the points overlap). The data were fitted to an exponential decay. Standard error bars from three determinations are shown

did not reveal any differences in local secondary structures between these two fusion species, thus, we suggest that uncoupling caused by codon specific context obstacles around the initiation region may contribute to more rapid mRNA decay, according to observations described elsewhere [37, 46]. Taking into consideration the complexity of several factors that impact efficiency of translation within a downstream of initiation codon sequence window and their interdependence ambiguity in creating stability of mRNA [47-51] we cannot exclude additional features that influence this rate-limiting initiation step of translation. Moreover, we reproducibly 
observed differences in migration pattern of the particular GFP hybrid produced by both T7 or bacterial expression systems, when using SDS polyacrylamide gels. Many of those did not correlate with their expected molecular weights, which are almost equal $(27.6 \mathrm{kDa})$ to the wildtype GFP (26.9 kDa) (Fig. 2c, d). Presumably, this reflects differences in protein stability dependent on the amino acid composition of $\mathrm{N}$-terminal tails.

\section{GFP reference normalization requirements}

The obtained results strongly indicate requirement of the proper positive reference with corresponding composition of natural amino acids to normalize fluorescence intensity of rescued frameshifted $g f p$ mutants. In Fig. 5 fluorescence levels of variants of $g f p T_{6}-1$ and $g f p T_{7}-1$ series with various amino acid composition were presented. As shown (Fig. 5b) efficiencies of slippage are comparable within groups only after normalization to fluorescence of corresponding in-frame GFP0 controls (black columns vs. white columns).

\section{Conclusions}

In this work, we present experimental evidence for utility of GFP reporter for accurate estimation of $\mathrm{A} / \mathrm{T}$ homopolymeric sequence contribution in transcriptional slippage induction. We showed that the intensity of GFP fluorescence mainly depended on the number of retained natural amino acids, thus fluorescence raw data need to be referred to appropriate positive control. This GFP reporter-based tool can be easily applied to study of any slippage sequence.

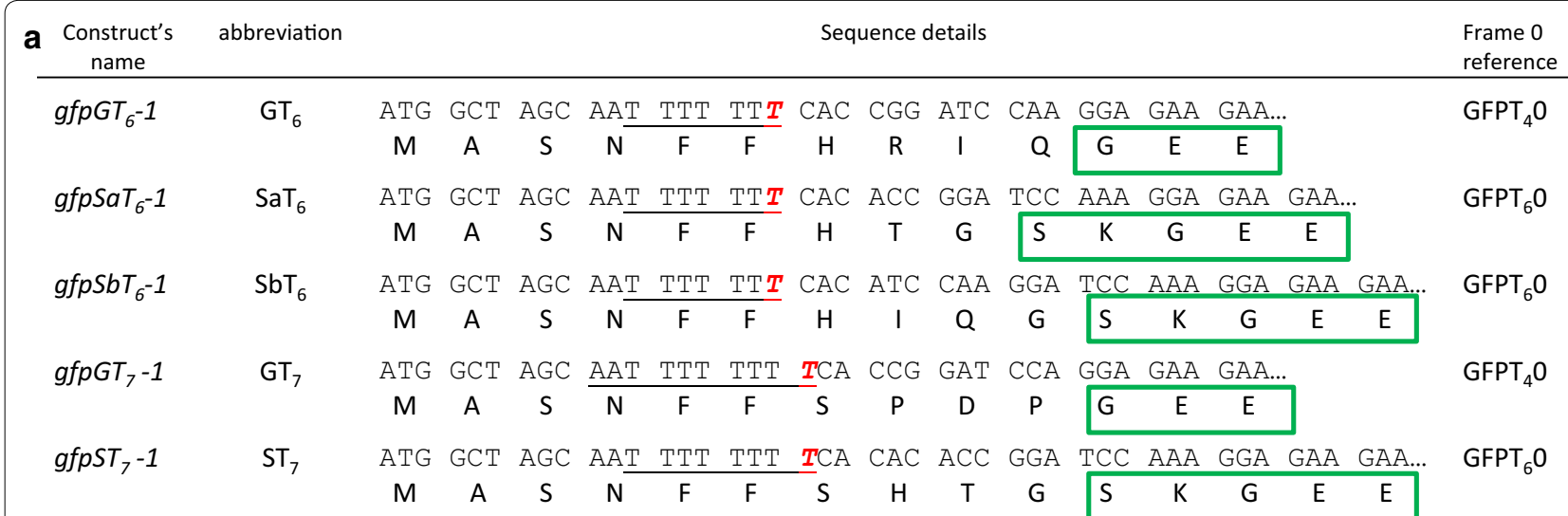

b

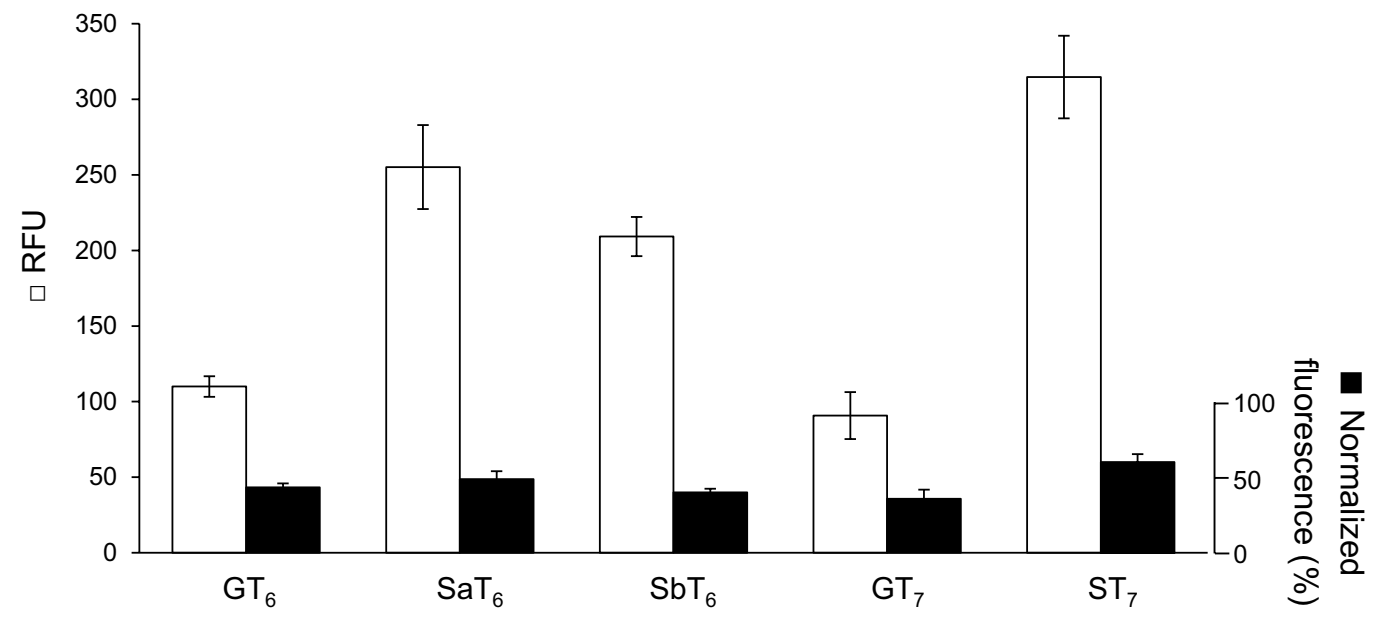

pETmingfp-based constructs carrying-1 frameshifted gfp gene

Fig. 5 Slippage efficiency of the poly $\left(T_{6} / T_{7}\right)$ gfp-1 expressed genes presented as RFU and after normalization to fluorescence of corresponding GFP reference. a Sequence details of compared hybrids constructs with poly $\left(T_{6}\right)$ and poly $\left(T_{7}\right)$ (underlined) after transcriptional slippage by a single T insertion (italic red). b Fluorescence of hybrids shown in arbitrary units (white bars) and relative fluorescence values after normalization to fluorescence of a proper in-frame positive control values (black bars), respectively. Errors bars represent standard deviations from three independent experiments 


\section{Additional file}

Additional file 1: Figure S1. GFP fluorescence is proportional to a bacterial culture yield. The relative level of Gfp fluorescence in ER2566 cultures expressing 0 frame gfp ( $p E T_{g f p A_{6}} 0$ ) (circles) and -1 frameshifted $g f p A_{5}-1$ (pETmin $A_{2}$ gfp-1) (diamonds) $\left(1 \mathrm{mM}\right.$ IPTG by $1 \mathrm{~h}$ at $37^{\circ} \mathrm{C}$ ). The black line represents the regression line between normalized measurements of GFP fluorescence and bacterial pellet abundance, serially diluted $\left(r^{2}=0.998\right.$ and 0.992, as determined by regression analysis). Table S1. Plasmids used in this study. Table S2. List of oligonucleotides used in this study to amplify and duplex DNA annealing.

\section{Authors' contributions}

MS and EW conceived and designed the research; EW, DK, MSz and MS performed the experiments, analyzed the data. EW and MS wrote the manuscript. All authors read and approved the final manuscript.

\section{Acknowledgements}

Not applicable.

\section{Competing interests}

The authors declare that they have no competing interests.

\section{Availability of data and materials}

All data and materials will be available upon request.

\section{Consent for publication}

Not applicable.

\section{Ethics approval and consent to participate}

Not applicable.

\section{Funding}

This work was supported by the National Science Centre (Poland) (2012/07/ BNZ2/01782 to M.S.)

\section{Publisher's Note}

Springer Nature remains neutral with regard to jurisdictional claims in published maps and institutional affiliations.

Received: 19 June 2018 Accepted: 17 September 2018 Published online: 21 September 2018

\section{References}

1. Chalfie M, Tu Y, Euskirchen G, Ward WW, Prasher DC. Green fluorescent protein as a marker for gene expression. Science. 1994;263:802-5.

2. Chudakov DM, Matz MV, Lukyanov S, Lukyanov KA. Fluorescent proteins and their applications in imaging living cells and tissues. Physiol Rev. 2010;90:1103-63.

3. Shaner NC, Patterson GH, Davidson MW. Advances in fluorescent protein technology. J Cell Sci. 2007;120:4247-60

4. Atkins JF, Loughran G, Bhatt PR, Firth AE, Baranov PV. Ribosomal frameshifting and transcriptional slippage: from genetic steganography and cryptography to adventitious use. Nucleic Acids Res. 2016:44:7007-78.

5. Murakami KS. Structural biology of bacterial RNA polymerase. Biomolecules. 2015;5:848-64.

6. Wons E, Furmanek-Blaszk B, Sektas M. RNA editing by T7 RNA polymerase bypasses InDel mutations causing unexpected phenotypic changes. Nucleic Acids Res. 2015;43:3950-63.

7. Rosenberger RF, Hilton J. The frequency of transcriptional and translational errors at nonsense codons in the lacZ gene of Escherichia coli. Mol Gen Genet. 1983;191:207-12.
8. Baranov PV, Hammer AW, Zhou J, Gesteland RF, Atkins JF. Transcriptional slippage in bacteria: distribution in sequenced genomes and utilization in IS element gene expression. Genome Biol. 2005;6:R25

9. Gordon AJ, Satory D, Halliday JA, Herman C. Heritable change caused by transient transcription errors. PLoS Genet. 2013;9:e1003595.

10. Gordon AJ, Satory D, Halliday JA, Herman C. Lost in transcription: transient errors in information transfer. Curr Opin Microbiol. 2015:24:80-7.

11. Rockah-Shmuel L, Tóth-Petróczy Á, Sela A, Wurtzel O, Sorek R, Tawfik DS Correlated occurrence and bypass of frame-shifting insertion-deletions (InDels) to give functional proteins. PLoS Genet. 2013;9:e1003882.

12. Tamas I, Wernegreen JJ, Nystedt B, Kauppinen SN, Darby AC, GomezValero L, Lundin D, Poole AM, Andersson SG. Endosymbiont gene functions impaired and rescued by polymerase infidelity at poly $(A)$ tracts. Proc Natl Acad Sci USA. 2008;105:14934-9.

13. Wernegreen JJ, Kauppinen SN, Degnan PH. Slip into something more functional: selection maintains ancient frameshifts in homopolymeric sequences. Mol Biol Evol. 2010;27:833-9.

14. Sambrook J, Fritsch EF, Maniatis T, editors. Molecular cloning: a laboratory manual. Cold Spring Harbor: Cold Spring Harbor Laboratory Press; 1989.

15. Guzman LM, Belin D, Carson MJ, Beckwith J. Tight regulation, modulation, and high-level expression by vectors containing the arabinose PBAD promoter. J Bacteriol. 1995;177:4121-30.

16. Dubendorff JW, Studier FW. Controlling basal expression in an inducible T7 expression system by blocking the target T7 promoter with lac repressor. J Mol Biol. 1991;219:45-59.

17. Miller WG, Lindow SE. An improved GFP cloning cassette designed for prokaryotic transcriptional fusions. Gene. 1997:191:149-53.

18. Cormack BP, Valdivia RH, Falkow S. FACS-optimized mutants of the green fluorescent protein (GFP). Gene. 1996:173:33-8.

19. Furmanek-Blaszk B, Boratynski R, Zolcinska N, Sektas M. M1.Mboll and M2.Mboll type IIS methyltransferases: different specificities, the same target. Microbiology. 2009;155:1111-21.

20. Pfaffl MW. A new mathematical model for relative quantification in realtime RT-PCR. Nucleic Acids Res. 2001;29:e45.

21. Gonzalez de Valdivia El, Isaksson LA. A codon window in mRNA downstream of the initiation codon where NGG codons give strongly reduced gene expression in Escherichia coli. Nucleic Acids Res. 2004;32:5198-205.

22. Martin CT, Muller DK, Coleman JE. Processivity in early stages of transcription by T7 RNA polymerase. Biochemistry. 1988;27:3966-74

23. Hecht A, Glasgow J, Jaschke PR, Bawazer LA, Munson MS, Cochran JR, Endy D, Salit M. Measurements of translation initiation from all 64 codons in E. coli. Nucleic Acids Res. 2017:45:3615-26.

24. Raghunathan G, Sokalingam S, Soundrarajan N, Madan B, Munussami G, Lee SG. Modulation of protein stability and aggregation properties by surface charge engineering. Mol BioSyst. 2013;9:2379-89.

25. Dopf J, Horiagon TM. Deletion mapping of the Aequorea victoria green fluorescent protein. Gene. 1996;173:39-44.

26. Li X, Zhang G, Ngo N, Zhao X, Kain SR, Huang CC. Deletions of the Aequorea victoria green fluorescent protein define the minimal domain required for fluorescence. J Biol Chem. 1997;272:28545-9.

27. Liu SS, Wei X, Dong X, Xu L, Liu J, Jiang B. Structural plasticity of green fluorescent protein to amino acid deletions and fluorescence rescue by folding-enhancing mutations. BMC Biochem. 2015:16:17.

28. Arpino JA, Reddington SC, Halliwell LM, Rizkallah PJ, Jones DD. Random single amino acid deletion sampling unveils structural tolerance and the benefits of helical registry shift on GFP folding and structure. Structure. 2014;22:889-98.

29. Rodríguez-Mejía JL, Roldán-Salgado A, Osuna J, Merino E, Gaytán P. A codon deletion at the beginning of green fluorescent protein genes enhances protein expression. J Mol Microbiol Biotechnol. 2017:27:1-10.

30. Cannarozzi G, Cannarrozzi G, Schraudolph NN, Faty M, von Rohr P, Friberg MT, Roth AC, Gonnet P, Gonnet G, Barral Y. A role for codon order in translation dynamics. Cell. 2010;141:355-67.

31. Hersch SJ, Wang M, Zou SB, Moon KM, Foster LJ, Ibba M, Navarre WW. Divergent protein motifs direct elongation factor P-mediated translational regulation in Salmonella enterica and Escherichia coli. MBio. 2013;4:e00180-00113.

32. Cheng $L$, Goldman E. Absence of effect of varying Thr-Leu codon pairs on protein synthesis in a T7 system. Biochemistry. 2001;40:6102-6.

33. Irwin B, Heck JD, Hatfield GW. Codon pair utilization biases influence translational elongation step times. J Biol Chem. 1995:270:22801-6. 
34. Quax TE, Claassens NJ, Söll D, van der Oost J. Codon bias as a means to fine-tune gene expression. Mol Cell. 2015;59:149-61.

35. Goodman DB, Church GM, Kosuri S. Causes and effects of N-terminal codon bias in bacterial genes. Science. 2013;342:475-9.

36. Kosuri S, Goodman DB, Cambray G, Mutalik VK, Gao Y, Arkin AP, Endy D, Church GM. Composability of regulatory sequences controlling transcription and translation in Escherichia coli. Proc Natl Acad Sci USA. 2013;110:14024-9.

37. Presnyak V, Alhusaini N, Chen YH, Martin S, Morris N, Kline N, Olson S, Weinberg D, Baker KE, Graveley BR, Coller J. Codon optimality is a major determinant of mRNA stability. Cell. 2015;160:1111-24.

38. Tuller T, Zur H. Multiple roles of the coding sequence $5^{\prime}$ end in gene expression regulation. Nucleic Acids Res. 2015;43:13-28.

39. Bivona L, Zou Z, Stutzman N, Sun PD. Influence of the second amino acid on recombinant protein expression. Protein Expr Purif. 2010;74:248-56.

40. Stenström CM, Jin H, Major LL, Tate WP, Isaksson LA. Codon bias at the $3^{\prime}$-side of the initiation codon is correlated with translation initiation efficiency in Escherichia coli. Gene. 2001;263:273-84.

41. Sørensen MA, Kurland CG, Pedersen S. Codon usage determines translation rate in Escherichia coli. J Mol Biol. 1989;207:365-77.

42. Kudla G, Murray AW, Tollervey D, Plotkin JB. Coding-sequence determinants of gene expression in Escherichia coli. Science. 2009;324:255-8.

43. Li GW, Oh E, Weissman JS. The anti-Shine-Dalgarno sequence drives translational pausing and codon choice in bacteria. Nature. 2012:484:538-41.
44. Gutman GA, Hatfield GW. Nonrandom utilization of codon pairs in Escherichia coli. Proc Natl Acad Sci USA. 1989;86:3699-703.

45. Schoner BE, Hsiung HM, Belagaje RM, Mayne NG, Schoner RG. Role of mRNA translational efficiency in bovine growth hormone expression in Escherichia coli. Proc Natl Acad Sci USA. 1984;81:5403-7.

46. Boël G, Letso R, Neely H, Price WN, Wong KH, Su M, Luff J, Valecha M, Everett JK, Acton TB, et al. Codon influence on protein expression in E. coli correlates with mRNA levels. Nature. 2016;529:358-63.

47. Brock JE, Paz RL, Cottle P, Janssen GR. Naturally occurring adenines within mRNA coding sequences affect ribosome binding and expression in Escherichia coli. J Bacteriol. 2007;189:501-10

48. Stenström CM, Isaksson LA. Influences on translation initiation and early elongation by the messenger RNA region flanking the initiation codon at the $3^{\prime}$ side. Gene. 2002;288:1-8.

49. Zhang $G$, Ignatova Z. Generic algorithm to predict the speed of translational elongation: implications for protein biogenesis. PLoS ONE. 2009:4:e5036.

50. Castillo-Méndez MA, Jacinto-Loeza E, Olivares-Trejo JJ, Guarneros-Peña G, Hernández-Sánchez J. Adenine-containing codons enhance protein synthesis by promoting mRNA binding to ribosomal 30 S subunits provided that specific tRNAs are not exhausted. Biochimie. 2012;94:662-72.

51. Zamora-Romo E, Cruz-Vera LR, Vivanco-Domínguez S, Magos-Castro MA, Guarneros G. Efficient expression of gene variants that harbour AGA codons next to the initiation codon. Nucleic Acids Res. 2007;35:5966-74.
Ready to submit your research? Choose BMC and benefit from:

- fast, convenient online submission

- thorough peer review by experienced researchers in your field

- rapid publication on acceptance

- support for research data, including large and complex data types

- gold Open Access which fosters wider collaboration and increased citations

- maximum visibility for your research: over $100 \mathrm{M}$ website views per year

At $\mathrm{BMC}$, research is always in progress.

Learn more biomedcentral.com/submissions 